\title{
Marisquadoras of the Shellfish Revolution: \\ The Rise of Women in Co-management on Illa de Arousa, Galicia $^{1}$
}

\author{
Sarah Keene Meltzoff
}

\section{Introduction}

Socorro Oteiro wades into shore through Illa's clear cold water, her bucket brimming with fine clams. This moon phase, extreme low tides around the island have made for optimal harvesting conditions. A score of other marisquadoras (women shellfishers) bend over rakes and hoes combing the wet, sandy tidal flats, each digging to reach the 4-kg. quota of almeha fina (Venerupis decussata, or fine clams). Having her own quota, Socorro peels off hipboots, climbs into her jeep, and heads back into town ahead of the others to oversee the daily auction market.

Socorro is the leader of the marisquadoras' unprecedented political rise within the cofradia, the all- inclusive community fisheries organization that embraces both male and female owners and workers on land and water. Given that cofradías (literally "brotherhood") have been male-run for centuries in Galicia, the active role of the marisquadoras signals a significant change in women's status and political power. Socorro herself, has already served as vice president of the cofradía, and has been president of the cofradia's Producers' Organization for four of its first six years. Four more full-time marisquadoras are officers of the Producers Organization consejo (council). All five women are on the cofradía's twelve-person cabildo (board).

Another unprecedented change in the cofradía system has been the bureaucratization of Illa's shellfishery, led by a new breed: the professional cofradía director. However, Illa's director has had the enormous added benefit of being local. Therefore, besides having the necessary knowledge to form the Producers' Organization and other committees required by Xunta and EC regulations, he could successfully encourage women to run for political

1. This article is based on Galician fieldwork in 1985-1986 and 1989-1991. I am grateful for the support of the National Science Foundation. I delivered an initial version as a conference paper entitled "The Rise of Women in Fisheries Management: The Marisquadoras of Illa de Arousa, Galicia” with Kenny Broad, for Bonnie McCay's panel on Fisheries comanagement at the 1992 World Fisheries Congress, Athens, Greece. The proceedings were published in English. For insights and warm hospitality, I am indebted to Enrique Lopez Veiga and the Xunta, and Manuel Lojo and the marisquadoras of Illa. Rod Neumann, Kenny Broad, Edward LiPuma and Alaka Wali provided invaluable critiques of earlier versions of this article. I also thank Gina Maranto for her astute editorial advice. And, I gratefully acknowledge the JPE anonymous reviewers for providing useful ideas which I've incorporated into the text. 
office and preach to them the ethics of conservation. A shellfish revolution has stimulated the resurrection of the cofradía system, dormant for decades during Franco's rule. This, combined with the bureaucratization of Illa's cofradía, has led to a new acceptance of women as professional leaders and as wielders of political power.

The shellfish revolution, as it has been dubbed by Galicia's government, the Xunta, was generated by two major changes in Spain: (1) large-scale infrastructure development (V.Gonzalez 1980); and (2) inclusion in 1986 into the European Community (EC) and its markets. Marisquadoras' income-earning potential soared with the development of broad national and EC markets for shellfish, escalating demand and the value of their fine clams up to US $\$ 40$ per $\mathrm{kg}$. Thus, marisquadoras grew more financially independent, selling their own shellfish instead of marketing their male relations' fish or earning cannery wages.

With the revolution, Illa women have only expanded the social and economic power that they already had. That Illa women, like fish-marketing women in many parts of the world, have tended to have a relatively high degree of mobility, economic savvy, and income, has given them some independence and stature within fishing communities (S.Cole 1991, J.Nadel-Klein and D.Davis 1988, R.Pollnac 1988, P.Thompson 1985, T.Volkman 1994). S.Cole (1991) further describes the social reality of women's dominance in fishing households in Portugal, where women identify themselves in terms of their productive labor and their hard-working status. J.Nadel-Klein and D.Davis (1988) emphasize the complementarily of women's and men's labor in subsistence fishing communities, and how women's livelihood and sense of self derives from the fishery. P.Thompson (1985) argues sexual division of labor in fisheries has multiple implications for women's social position. There seems to exist a link between women's mobility and status and their political claims.

In Illa's case, the marisquadoras increased their status by staking political claims, and assuming political office and decision-making roles within the cofradia and its EC marketing arm, the Producers' Organization (OP). The Xunta noted Illa's advances in developing an OP and co-management strategies that included marisquadoras. The Xunta wished to take Illa as a model of inclusive local-level, fishery co-management. The comanagement model, itself, has been advocated as a future ideal (C.Dyer and J.McGoodwin 1994, S.Jentoft 1989, B.McCay and J.Acheson 1987, J.McGoodwin 1990). A widely accepted definition of co-management is:

a shift away from autocratic and paternalistic modes of management to modes that rely on the joint efforts of traditional fisheries specialists and fishing peoples (McGoodwin 1990:189-190).

Co-management includes user groups in local consensual management because of their practical knowledge in decision making. The following underscores the advantages of co-management:

When folk knowledge and local perspectives are incorporated into a larger management system as co-management, they may make the difference between the system's having legitimacy or not, having local relevance or not, and in general operating more rather than less effectively (E.Pinkerton 1994:320).

Overall, co-management is supposed to increase rationality in management and create more legitimate regulations, thereby motivating user groups to follow regulations 
(S.Jentoft and K.Mikalsen 1994:288). Thus, Illa's marisquadoras were touted by the Xunta as vital to the co-management political process.

Two underlying cultural factors helped explain the marisquadoras' political rise in the cofradia, and their ability to manage themselves in the Galician shellfishery. First, they had always controlled the means of production, requiring only hoes and boots instead of more capital-intensive fixed assets such as boats and nets. Second, control over family income by women, including money from their own productive activities, had been a longstanding Galician tradition. Such control of the means of production and of income kept women from becoming marginalized in fishing communities. S.Cole (1991) describes a similar situation for women in Portuguese fishing households. Within this context, Illa women entered the local politics of fishing.

Organized along two story lines, this paper threads both together in order to understand the political ecology of Illa. The first line is that of the macrostructural changes that made up the shellfish revolution. Outside Illa's fishing culture, these political economic events are categorized by EC involvement in Galician fisheries and post-Franco infrastructure development. The second line is that of the local culture of the marisquadoras. Political ecology calls for such a multilevel, historical approach that links the local culture to macrostructural changes (R. Bryant 1992, R.Neumann 1992). In Illa, the macro and the local converge when the cofradia is in the unique social situation of hiring a local professional director who is able to initiate progressive shellfish comanagement. The marisquadoras are empowered in the process, joining in comanagement and attaining a new community status. This paper examines the convergence that facilitates change. It explores how women's new political status is not invented by an outsider, but rather is built upon existing values, deriving from the cultural roles of the marisquadoras, the sexual division of labor in shellfishing and the position of women as family bankers.

\section{Bridging the Insular World of Marisquadoras}

Illa de Arousa is an insular Galician fishing community in the Ria de Arousa, surrounded by broad, sandy shellfishing beds. ${ }^{2}$ Until this decade, only fishing boats and an hourly ferry service connected Illa to the outside world. Women courted and married endogamously. Their lives revolved around a world of family subsistence farming and shellfishing, marketing of male relatives' fish, and wage work for local canneries. Women manage the family finances. Even in the traditional Galician wedding ceremony, the priest hands money to the groom who symbolically turns and passes it on to the bride. As fish marketers, Illa women earned money locally by going house to house. They also took the ferry across to the mainland to vend fish in neighboring towns where people called them regateiras--from regatear, to haggle loudly--a name that embarrassed some women and kept them on Illa.

The most drastic physical change, one that socially transformed Illa, was the building of a bridge to the mainland. This bridge was constructed during Spain's period of infrastructure development in the post-Franco democracy. Before the bridge was completed in 1984, Illa people led an insular existence, separated from "el continente"--a

2. Rias are deep, fjord-like bays biting into Galicia's Atlantic coastline. 
local term for the mainland that illustrates social distance. Illa, like the rest of Galicia, was relatively isolated because of its dependence on ferries, and because of poor roads, and the dearth of telephones. The lack of modern refrigerated trucks further retarded the development of a Galician shellfish market.

Before the bridge, Illa people owned approximately 400 cars that they kept parked across the ria on el continente. On the island itself there were only 10 to 15 cars so that people relied on foot transportation. At the beginning of low tide, marisquadoras walked together in large groups along the dirt tracks to reach the tidal flats. People designed their insular community (space and place) to accommodate transportation by foot; settlement concentrated around the fishing port with few houses elsewhere.

Less than a decade after the construction of the bridge, car ownership had almost doubled. Illa people now drove 700 cars back and forth over the bridge. A sign on the Illa side of the bridge bore a graffiti reminder that one was leaving for "el continente". Now marisquadoras carpool around the island instead of walking. This way thus saves traveling time and can rapidly check which tidal flats are best each day. With ease of transport, houses and small businesses spread around the island, creating a new pattern of settlement.

Although the bridge has made shopping, visiting, and obtaining medical care from " $e l$ continente" more convenient for Illa's women, it has also opened Illa's accessibility to outsiders. During the summer, tourists increased Illa's population by one-third. The marisquadoras grew rightfully concerned that too much activity on the flats--their fishing grounds--would damage their fishery. The women felt that if each tourist ate just a clam or two, there would be a negative impact on the harvest. Therefore, the women took a united political stand against paving roads that would make their beach sites too accessible.

The bridge opened up Illa socially, so that 20 percent of the youth now married outside the community. Almost all the couples, however, decided to settle on Illa to take advantage of the rich shellfishing. Illa had had a positive public image around the Ria de Arousa. Illa de Arousa--whose very name means "gracious island"3 (Samuel Armistead, UC Davis Department of Spanish, personal communication, 1995)--was considered to be safe, bountiful, and beautiful. Both men and women marrying into Illa were made welcome by the community, being allowed to join the cofradía and apply for their own shellfish licenses.

Positive attitudes towards educating rural women in the post-Franco era coincided with easier access to education. With the bridge, boys and girls were encouraged to attend high school, which had always been on the mainland. The basic quality of education, family expectations, and girls' desire to stay in secondary school, vastly improved. None of the professional marisquadoras--of the generation between 30 and 50 years old--had gone beyond primary school, but their daughters were attending high school. Girls still start training in the marisquadora's art as soon as they can qualify for shellfish licenses at age 16 . While completing secondary education, they begin by accompanying friends and relations to dig during the peak times, at the lowest tides.

3. Originally, local people probably described Illa de Arousa in terms of its nature, the Gallego word arousa having a primary meaning of "breezy". Later, the meaning would have shifted to "gracious", the secondary meaning (Samuel Armistead, UC Davis, Department of Spanish, personal communication, 1995). 


\section{The Marisquadora Art: The Change to Professionalism}

For generations the category marisquadora remained loose, undefined by legal status, unlicensed, simply one of the multiple defining work roles for women. Typically, marisquadoras, like all other artisanal fishing ${ }^{4}$, were beyond fisheries regulation and enforcement in Galicia. Regulation was external, alien, to be dodged. The ria communities were not involved in formal management. Fishers harvested how, where, and when they wished, including taking juveniles. Boundaries between community territories were informal and kept by mental maps; people often crossed over into each others areas.

Before the sardine crisis of the 1960s, women spent little time shellfishing because the market for shellfish was so weak. Shellfishing, like gardening, was only one of several subsistence activities for women. Women harvested bivalves for their family's diet; crabs were thrown on the fields as fertilizer. Shellfishing could only augment family income and diet. Many Illa women marketed fish in towns on the ria, primarily Cambados, Vilanova, and Villagarcia. Women also supplied the labor for Illa's five sardine canneries which operated until 1960.

The canneries initiated the first big commercial market for shellfish during the 1960s sardine crisis. At this time the canneries began to substitute shellfish in the slowest season (October-February) in order to supplement the poor supply of sardines. Women, encouraged by this new market demand, intensified harvesting clams, cockles, and other bivalves. In turn, the shellfish revolution with its escalating market, intensified women's shellfishing. Given new licensing regulations, almost all Illa women between the legal ages of 16 and 65 were motivated to obtain licenses. Thus, a licensed class of marisquadoras evolved with the shift towards regulation and management. In 1992, marisquadoras officially numbered approximately 800 out of Illa's total population of 4,900 .

Marisquadoras, practicing the old art, sometimes wade out into waste-deep cold water. Wading on the tidal flats has been perceived by ria fishermen as a woman's art. Marisquadoras exclusively shellfish in the tidal zone from shore, using methods that require almost no capital input or investment beyond a bucket, boots, and a rake or hoe. They still work in small friendship groups, often composed of mothers, daughters, and sisters. Men, for their part, only approach shore in small launches. ${ }^{5}$ They never wade, leaving that technique to women. It is taboo for men to wade in the water as a fishing technique; getting wet in this fashion is considered humiliating and seems to have a symbolic content akin to drowning. A parallel symbolic boundary exists among the sargaceiras (seaweed harvesters) down the coast in northern Portugal, and has been nicely analyzed by E.Hoefnagel (1991:53-54). Illa men, working two to a boat, use long wobbly handled rakes to harvest in a zone up to $6 \mathrm{~m}$ deep where less commercially valuable types of shellfish thrive.

Marisquadoras thus have their own gender-specific zone where they do not have to compete with fishermen despite the increased value of the resource. Rather, women

4. Spanish refers to each type of fishing as an art, reflecting respect and understanding for the different skills and knowledge involved in each one.

5. Illa men still operate a number of dornas, the traditional curve-bowed dories painted black on top and white underneath. 
compete among themselves. They have self-selected into a new, elite group of full-time diggers who call themselves "professionals". Other women call them "serious", a high Spanish compliment meaning dedicated and hard-working. ${ }^{6}$ These professionals have separated themselves from the other Illa women, becoming competitive, preferring to harvest alone. A professional marisquadora could earn about US $\$ 90$ a day in 1992, an income equivalent to two men shellfishing by boat. Approximately 10 percent of the 800 marisquadoras identified themselves as professionals in 1992. These were full-timers with recognized expertise who were most intent and successful; another 15 percent classified themselves as semiprofessional. These two groups together, one quarter of the Illa marisquadoras had gathered knowledge from long experience about which beds were softest, and where the biggest and finest species of clams lay. The majority of women, holding the identical license as professionals, however, continued to harvest only on the month's lowest tides. They could produce extra income, taking advantage of their right to a license as members of a community blessed with rich shellfish grounds. The professionals, on the other hand, claimed both wealth and political power within the cofradía system establishing co-management in Illa.

\section{Resurrection of the Cofradía and Co-management}

For generations, each coastal community had had a cofradía, or port fishing association, comprised of every boat owner and fisher, as part of Spain's system of local governance (S.Meltzoff and E.LiPuma 1986). Cofradías in Galicia were largely moribund during Franco's regime. ${ }^{7}$ In the post-Franco democracy, Illa continued to maintain its filosofía isleña, one of relative isolation characterized by furtivo fishing: without any thought to law and conservation practices, and individual family marketing. In other words, Illa practiced totally unmanaged exploitation, a condition that continues to typify the other fishing communities in the ria.

The first new national government, pre-EC and pre-Xunta, paid scant attention to conservation, resource management, or marketing in the littoral fishing sector. Local markets for shellfish were informal and unorganized, producing minimal cash. Individual men took boats around to buy the shellfish directly from those fishing. Women, however, carried out the bulk of the marketing in line with their family role as bankers.

In 1983, with the bridge under construction epitomizing infrastructure development, and the nascent shellfish revolution, Illa's young men sensed economic possibilities for their island's fertile shellfish grounds. They decided to revive their cofradía as a vehicle for marketing and representing village fishing interests. First the male youth elected themselves to the cofradía directorate in July 1983, then they immediately moved to call upon one of their few university-educated peers to become the professional director.

Hiring a professional director was a radical, bold move, unlike other cofradías in the ria. The new director, Manuel Lojo, had grown up on Illa with his grandparents, learning to fish before studying chemistry at the University of Santiago. Spending his weekends at home on Illa, Lojo felt an ideological commitment to developing Illa's shellfish market. An avid member of the PSOE (Partido Socialista Obrero Español, the

6. S.Cole notes the same praise as hard-working for Portuguese women(1991).

7. Franco died in 1975, ending an era. 
socialist party of Felipe Gonzalez), he believed that forming his ideal cofradía would fulfill the PSOE goal of local political action. Under Lojo's leadership, the cofradía started to represent Illa in: (1) establishing an organized shellfish lonja (auction market) that could take advantage of Galicia's improving transportation and communication system; (2) recruiting the professional marisquadoras into cofradía office and co-management; and (3) defining and negotiating island boundaries with warring neighbor fishermen and marisquadoras, thereby redefining property rights.

\section{Development of a Local Auction Market and Regulation System}

Arriving in August, Lojo's first move was to set up a temporary lonja in the town plaza in time for the October opening of the 1983 shellfishing season. Everyone had to sell their shellfish through the lonja's auction. In theory, a lonja regulates informal and individual marketing strategies, giving families higher prices for their product. On the one hand, Illa's new lonja system ended the individual market power of women to sell their family's catch anywhere. On the other, it brought a far greater profit for family shellfishing effort, generating more family income, as well as personal income, for women to manage. The lonja, as a centralized auction market, was able to maximize the economic return on shellfishing and empower the cofradía.

The first makeshift lonja in 1983, yielded 80 million pesetas for all shellfish. These were the total shellfish sales of 1,600 fishers: 800 marisquadoras and 800 fishermen. By 1986 , the cofradía could raise capital ${ }^{8}$ to build a spacious new lonja and headquarters by the seawall of Illa's port.

The lonja has become the hub of market activity as women arrive after low tide with their shellfish. The marisquadoras have been out digging for three to four hours, their backs sore, their feet frequently chilled even through high wading boots (an innovation introduced only in 1990). Along the seawall, men off-load their launches and carry up mesh bags of shellfish and their springy-handled, 10-meter rakes, unwieldy in the air. Each fisherman and marisquadora brings their daily catch inside the lonja, dumping it onto the floor and separating the different species into individual piles. Everyone places a slip of paper with their name on each pile to be sold. Buyers walk around jotting in their notepads, inspecting the size and quality of the different piles to plan their bidding before the auction.

The lonja auctioneer follows the system of starting high and heading low. Each of the five main types of bivalve has a distinct reputation for flavor, size, fleshiness and texture, and is priced accordingly. (Table 1)

8. The cofradia had raised capital from the following sources: 2 percentfrom the Xunta; 10 percent from Madrid (FROM); and 88 percent from a bank loan at 17.5 percent interest. By 1990, lonja shellfish sales had risen to 420 million pesetas for bivalves and 200 million pesetas for shrimp and crabs. The cofradia could keep two percent of these sales: one percent for paying the cofradia's operating expenses; and one percent allocated to pay off the cofradia's bank loan. 
In an attempt to conserve the resource, motivated by Lojo, the cofradía started imposing a tasa (daily quota) per person for the two most valuable types of bivalves. This was a move toward co-management occurring elsewhere in Europe, for example in Norway (S.Jentoft and T.Kristoffersen 1989). The cofradía tasa was actually stricter than the official Xunta tasa derived by Xunta biologists. For marisquadoras, the tasa was a choice of either $2 \mathrm{~kg}$ per day of almeja fina or $4 \mathrm{~kg}$ per day of almeja blanca. A pair of fishermen in a boat had a tasa of $6 \mathrm{~kg} /$ day for almeja blanca.

TABLE 1. : FIVE MAJOR TYPES OF BIVALVES IN ILLA 9

January 1992 prices 100 pesetas = US $\$ 1$

(1) Almeja san, or fina (Venerupis decussata). Fina was the top-of-the-line clam, selling for up to 4,000 pesetas per kg (US $\$ 40$ per $2.2 \mathrm{lbs}$ ) for the large size, and over 2,000 pesetas per $\mathrm{kg}$ when small. Almeja fina could only be found in the marisquadoras' tidal zone. It had a daily quota.

(2) Almeja vavosa (Venerupis pullastra) or blanca. Blanca ranged in price from 1,000-1,600 pesetas per $\mathrm{kg}$. It could be found and harvested by both fishermen in boats and marisquadoras on the tidal flats. It had a daily quota.

(3) Almeja rojo (Venerupis rhomboideus). Almeja rojo brought 700 pesetas per kg for assorted mixed sizes. They were not divided by size for auction. This clam was only accessible by boat, in the men's fishing area in deeper waters. Less valuable and found in deep water, it had no daily quota.

(4) Berberecho (Cardium edule, or cockles). Cockles sold for 100 pesetas per kg for smaller sizes and 400 pesetas per $\mathrm{kg}$ for large ones. Like reloje, it was found inshore by fishermen and marisquadoras, and was so common it had no daily quota.

(5) Reloje (Dosinia exoleta). Reloje was an inexpensive bivalve which sold for a mere 75 to 80 pesetas per $\mathrm{kg}$. Because it could be found in shallower water and inside the tidal zone, both marisquadoras and fishermen collected it. Although the Xunta did not considered it one of the four principal species of value for Galicia (1-4 of this Table) Illa's cofradía called it one of their five major shellfish. Common, it had no daily quota.

Marisquadoras who had fulfilled their own tasa, technically could help companions who still had room for more. Yet, marisquadoras, even the part-timers, had begun to feel competition among themselves. They all had equal access to Illa's tidal flats. It was becoming a sentiment that the clam left behind today could be collected tomorrow instead of given to another woman; this clam had enough economic value to warrant not sharing as before. Knowledge and drive now divided the women and determined potential income from the commons, as can happen in the shift to industrial fisheries (F.Berkes 1986, A.Davis 1985). Full-timers sometimes complained that the less-professional marisquadoras would follow them around in an attempt to cash in on their experience of the most fertile grounds. New conservation values along with new individualist values were evolving.

9. The Xunta considered the first four species on this Table as the most important species of shellfish in Galicia. Therefore, the Xunta analyzed them in terms of price, evolution of the fishing effort and sales, and information on production (Xunta 1990-91). 


\section{Professional Marisquadoras and the Cofradía}

The increasing value of shellfish was predictably intensifying exploitation (B.McCay and J.Acheson 1987). Thus, stricter regulations were becoming more palatable to the professionals in order to prevent overexploitation in the commons. Initially, Lojo had sought out these more "serious" marisquadoras, who as community fishers were already members of the cofradía by law, and encouraged them to run for offices in the cofradía. As a professional manager, he recognized potential allies. He understood the advantages of full representation and cooperation of all the distinctive fishing arts. Because shellfishing territory is divided by sex and method, with women and men practicing separate fishing arts, fishermen could see Lojo's logic of marisquadoras comanaging their own intensifying fishery. Resource rights might change with the revolution, and a new tenure system could develop around it within the context of the EC and the Xunta. Only the marisquadoras understood all the new intricacies and problems, from the laborintensive job of cleaning the flats of algae, (which smothers the shellfish in summer) to a newly regulated system of sieving out undersized juveniles for replanting.

In 1987, Illa's cofradía elected women to the directorate for the first time in its history. By 1991, professional marisquadoras totalled eight of 22 on the Junta General (public assembly, the directorate of the cofradía and the OP combined), and held five of the 12 positions on the Cabildo General (principal board). They had even won seats as officers, including Vice President of the cofradía. Women had been successfully drawn into comanagement and were accepted by the community. Through this route, "serious" marisquadoras were initiated into public decision-making positions, controlling the marketing and conservation of shellfish. Concomitant with the rise to public office and increased personal income, their status in the community rose. At this point, solidarity among professional marisquadoras was built on gender, insular kinship and friendship, as well as on a shared, lucrative fishing art (see A.Ong 1991 for a broader discussion of gender and labor politics). It was not so linked to class interests given the relatively equal economic and cultural capital of island fishing families where gender is a far more distinguishing labor factor (J.Nadel-Klein and D.Davis 1988).

Thus professional marisquadoras who became cofradía officials came to the forefront, particularly in the attempt to alter women's local concept of conservation. They faced the task of convincing the other marisquadoras of the importance of obeying daily quotas and similar conservation measures, like replanting juvenile bivalves. The part-time marisquadoras did not always respond well, despite the bonds of gender, kinship and friendship. New class divisions were emerging among the women. Some felt that professionals could better afford to follow a conservation plan because their skill allowed them to meet the daily quotas regardless of the tidal conditions. Even marisquadora officials still looked the other way on poor tides. When the water did not fall very low, many women harvested illegal juveniles in an attempt to fulfill quotas. For instance, in a surprise lonja inspection on a poor tide day, the Xunta inspectors confiscated $11 \mathrm{~kg}$ out of $200 \mathrm{~kg}$ of almeja fina; but on a good tide, inspectors found little illegal harvesting.

Infractions still were occurring in Illa because it was socially difficult to enforce laws against kin and old friends on a small, relatively endogamous island. Marisquadora officers participated in the decision whether or not to wield the cofradia's ultimate power, to withdraw a shellfish license and ban a member from Illa's communally held waters. This was the strongest threat, one the cofradía had never before carried out because social 
pressure had been enough. Now the function of bureaucratization was revealing itself in a system previously informally managed.

\section{The Xunta and Galician Fisheries Development}

Everyone agreed with the Xunta's assessment that there had been a Galician shellfish revolution. Galicians were harvesting at least 4,000 tons of bivalves from their rias in 1992, not counting mariculture production. FAO (Food and Agriculture Organization) considered Galicia's littoral waters, some of the richest in the world in phytoplankton, to provide the perfect natural conditions for shellfish.

Littoral Galician fisheries development and management had escalated since 1986 when Spain joined the EC and established the autonomous regional Xunta government of Galicia. The Xunta became responsible for local fisheries development and management. Under the leadership of the Xunta's Minister of Fisheries, Enrique Lopez Veiga, the Xunta began focusing on establishing a conservation program to maintain both the natural wealth and the artisanal lifestyle of shellfishing. Veiga's background was extraordinarily suited to this task. With a Ph.D. in marine biology, he directed ARVI (Cooperativa de Armadores de Pesca del Puerto de Vigo) in Vigo to become the most politically influential boat owners association in Spain. Through ARVI, Veiga influenced national level fisheries negotiations for adhesion to the EC, then went to Brussels in the first wave of Spaniards. At the EC, he worked at the highest technical level within the Fisheries Division, learning the EC's philosophy and management regulations for the three areas of EC competency in fisheries: fleet structure, resources, and market. After four years, Veiga was recruited back to Galicia by the Fraga government Xunta to become their Minister of Fisheries. Instituting new fish marketing and conservation plans, he dared enforce conservation measures for the first time in Galicia to control supply. Veiga was working closely with local fisheries organizations to stimulate the rational exploitation of their resources, offering financial help to cooperative communities like Illa. The Xunta would reward these few cofradías by funding special projects that aided co-management and conservation.

To reward Illa's self-motivation and diligence, Veiga sponsored the construction of a local bivalve hatchery. The hatchery would supply seed so marisquadoras could restock the tidal flats. Marisquadoras were looking forward to this advance in technology that promoted conservation and co-management. For Illa, the Xunta also had in mind a second project, a computer system for cofradía stock assessment. The technological advances for Illa, the hatchery and stock assessment computer program, had been carefully chosen by the Xunta not to replace local labor or disrupt the local lifestyle.

Cultural as well as environmental conservation were attempting to preserve artisanal fishing methods as well as jobs. The real shellfish revolution was not in harvesting technology, but rather in conservation management and marketing brought about by infrastructure development.

Veiga believed it was valid and important for each fishing art-- such as the marisquadoras' art--to participate in community based regulation. He thought of Illa as a model for successful co-management:embracing marisquadoras within the cofradia's political structure, and establishing professional leadership able to handle the EC's requirements for bureaucratized forms of management. Thus the Xunta viewed Illa's cofradía, and the marisquadoras who were comanaging their own fishery, as a potential model for balanced resource development. Furthermore, they hoped to replicate the formula by sponsoring and training cofradía bureaucrats in order to build both a managed 
market and an ethic of conservation. The Xunta intended to professionalize the leadership of more cofradías by offering financial assistance only to those that could produce a longrange exploitation plan. They hoped this would motivate cofradias to hire someone like Lojo, capable of drawing up such a professional plan. The Xunta failed to understand, however, that a major factor in Lojo's ability to manage the community was not his education, but rather his membership within the community. It is difficult for an outside manager to replicate the lifetime of social ties, local confidence, and political alliances that facilitate drawing all fishery groups, including the marisquadoras, into the management process.

\section{Illa's Uniqueness: The Contrast with Cambados}

The Xunta was focusing on the imperative of everyone having a professional cofradía director. The unusual social situation of having a local professional director on Illa, however, challenges the notion of general applicability. ${ }^{10} \mathrm{~A}$ brief look at the sharp contrast between Illa and a neighboring cofradía, Cambados, demonstrates how unique Illa is. An explanation of these historical cultural differences is beyond the scope of this paper, but the problems of generalizing Illa's situation will become clear.

Cambados was persisting in its hostility toward the Xunta, EC regulations, and regulations in general. Lacking the leadership and skills to organize under new regulations, Cambados hoped to endure without the development of co-management, stalling on government conservation efforts and management demands. The major visible distinction noted by the Xunta was that Cambados fishers had not hired a professional director for their cofradía. Whether such a qualified local person existed is questionable, and whether an outside director could have had significant influence is also debatable. Cambados would neither advance a conservation ethic nor form management organizations, like the OP. Cambados' cofradía continued to avoid co-management just as it had during the Franco regime.

In contrast to Illa, none of the Cambados marisquadoras wanted to be elected to the directorate of their stagnant cofradía. They only formed an informal political group. Along with many of the Cambados fishermen, they were attempting to sabotage government management efforts. Their community still clung to open, unregulated, freefor-all operating mode, maintaining renegade fishing status in the ria. In Cambados minds, strengthening a cofradía along EC and Xunta lines would threaten instead of bolster their livelihood. The Cambados patron mayor (cofradía president) had been a major fisherman, running two of the large-engined scallop trawlers unique to Cambados. He, himself, had a vested capital interest in catching as much as he could, continuing the historic unregulated system in a perceived unlimited resource base.

Cambados marisquadoras ardently held the same belief, mirroring the community as a whole. They viewed any cofradía efforts at management and regulation as alien to the community concept of common property in the ria. If there were no tasa and no size limits, each marisquadora could gather as many shellfish including juveniles as she could carry. There would be no conflict over whether or not to share the catch or leave it for oneself tomorrow, no budding internalized conservation ethic over sparing juveniles, as

10. Perhaps the concept of the influence of the "great man" should be resurrected, albeit without gender bias. 
has developed in Illa. As a result, Cambados women still worked in larger, less competitive groups. Like Illa, they had the solidarity generated by their fishing art, gender, kinship and friendship. But unlike Illa, Cambados marisquadoras were not developing new class distinctions based on a professional elite, competition and new individualist values.

Under pressure from the Xunta in 1992, the Cambados patron mayor called a cofradía meeting to present Xunta conservation measures. Cambados marisquadoras attended en masse, swarming the stage in protest, ripping down the patron mayor's pants, and leaving him to hobble away in his underwear. Interpreting the action as political activism, news quickly spread back to the Xunta of the marisquadoras' unwillingness to consider conservation.

Veiga, as the Xunta Minister of Fisheries, joked about his own risk confronting these strong-willed marisquadoras when he had to visit Cambados to explain his policies. Laughing, he described flying patrol over Ria de Arousa in the Xunta's fisheries management helicopter, instructing the pilot to hover over a group of Cambados marisquadoras who were digging out of season. Furious, they stood their ground shaking rakes and hoes at the helicopter, shouting curses. They did not run away despite the dousing whirlwind and the intimidating official status of the helicopter. Later at the meeting with Veiga, these marisquadoras complained how unfair it was to use helicopters to enforce conservation measures. They thought it would be more sporting if the Xunta reverted back to foot patrols so at least they could escape without losing the day's catch.

The Xunta, despite such local recalcitrance, continued to increase its enforcement role: patrolling inshore waters via two new government helicopters; sending out inspectors to confiscate undersized illegal catches; and imposing large fines for infractions. In the comparison between Illa and Cambados, it is clear why the Xunta loved and favored Illa.

The Xunta still was hoping that the management and conservation differences between Cambados and Illa could be bridged by hiring a professional director. In light of the Cambados case, the general applicability of Illa as a model for co-management is thrown into question.

\section{Fishing War Among Neighbors}

Despite a 1974 Madrid law requiring physical demarcation of municipal water boundaries, the Ria de Arousa fishers still operated under the historical system of locally recognized, undemarcated boundaries. For villages like Cambados and Illa, this system was viable as long as the value of the resource was low. This is a common pattern in what are called "folk management systems" (F.Berkes 1986, C.Dahl 1988, A.Davis 1985). When the shellfish were not so valuable and the market was still unorganized, few had minded neighbors working in their areas. The strong concept of community property rights over local submerged flats and waters triggered conflict when the shellfish revolution escalated the value of shellfish.

By 1983, tension over fishing grounds in the ria had escalated to the point of "la guerra" (war) between Illa, Cambados, and the other neighboring shellfishing villages. The new importance of shellfishing had begun to motivate communities to defend and define fishing territories. Men started to carry guns when fishing, and marisquadoras wielded hoes. They labeled people from neighboring villages, "robbers." And in the 
course of the escalating conflict, those havesting within the other's traditional waters had to duck bullets.

Upon being hired by the cofradía, Lojo helped establish the cofradia's own unarmed vigilante system. More importantly, he started the process of negotiations and compromises leading to the first legal government recognition of Illa's submerged territory. One dark night, Lojo recalled crossing the ria in a boat to have dinner in a rival fishng village with the "robbers" in order to reach a ceasefire and develop a plan to honor each other's territory. Within this tense setting, he had brought along his one year old son, a significant cultural demonstation of good will. By mutual agreement, Lojo finally was able to bring aoubt peace between Illa and the other fishing villages. And in 1986, thanks to Lojo's foresight, Illa received government approval of community boundaries, and for the first time set up markers to claim waters--balizarse. Neighboring villages were slower to petition the government to gain legal rights over submerged territory. As late as 1991, Cambados still lacked formal markers, choosing instead to ignore bureaucracy in favor of historical rights.

\section{Bureaucratization by the EC: Formation of Producers Organizations}

In compliance with EC Regulation No. \#3796 (1981), as soon as Spain joined the EC, Spanish cofradías began establishing Producers' Organizations (OP). Because Lojo had been attending government organizational meetings at FROM in Madrid, Illa was able to set up OP 20 right away. Lojo felt it was symbolic that OP 20 was born on his own birthday: 18 December 1986.

OPs were supposed to carry out the market policy of the EC. The EC market policy aimed to control the prices of abundant species with industrial applications. Cofradía leaders could help maintain prices by controlling supply through a strict system of tasas (daily quotas). When fishers limited their daily catch, conservation of the resource was an added benefit.

According to the Xunta, of the seven shellfish OPs in Galicia, only Illa's OP 20 and another in Vigo functioned. The rest were referred to as fantasmas (ghost OPs). Xunta officials felt it was unrealistic to expect Galicia, with over a thousand small fishing ports, to be able to "rationalize" and control the various markets, the EC ideal. Instead, the Xunta wanted cofradias, once qualified as OPs, to focus on conservation management techniques.

The EC stimulated OP formation by subsidizing each new OP for the first five years of operation. Any group of producers could form an OP according to EC law, as long as it was formed from below by the "free will of the producers." A cofradia that wished to set up an OP and benefit from the EC subsidy found itself in a strange position because cofradias were legally considered to be established "from above." Cofradias, therefore, had to form a secondary organization as their OP. In an effort to simplify local fisheries politics, the Xunta was trying to change the legal semantics so that both cofradías and boat owners associations could double as OPs without being forced to form a duplicate organization. Vying factions would have one less arena to play in. Because the pool of politically motivated people was limited in a small port, such as Illa, the identical people had to comprise the leadership of both cofradía and OP, with only a shift in titles. For example, Illa's cofradía president was also the treasurer of OP 20. 
The technical aspects of the OP demand bureaucratized leadership. A major role of the $\mathrm{OP}$ is to withdraw products if prices fall below the annual "withdrawal price." Because the EC organized the OP system before Spain joined, an historical deficit existed. The listed species failed to include important market species fished by Spain. The Xunta therefore wanted to add key species to the list. But because there was no need to subsidize luxury species whose prices remained stable, almeja fina would remain unlisted, like turbot and sole. On the other hand, less valuable bivalves and mussels needed price protection.Each year, the EC sets a "guide price" for every listed species. The guide price is used to determine the reference price and the withdrawal price. Imports have to be at least as expensive as the reference price, or else an EC tax is imposed. Thus, reference prices are a tool to fight against third states, like Morocco, importing competitive products.

The withdrawal price, depending on fish size, would be 70 percent to 90 percent of the guide price. Using sardines as an example, the sardine OP pays the sardine fishermen the withdrawal price. In principle, their OP should have funds available from sardine sales in the lonja. In reality, Madrid's FROM and especially the EC pays the withdrawal price. In sum, this EC price support works by subsidizing up to 20 percent of the catch. But, in order to encourage the OP to control prices, payments are reduced as the amount withdrawn for subsidy approaches 20 percent. Once 20 percent of the catch is withdrawn during the year, the EC ends aid. Most fishers are vague about how this system functions, yet they realize it is basically a price support. The OPs in charge of managing this system are not simple, and as one can see, tend to demand professional management.

\section{Gender Balance Between Shellfishing and Mussel Mariculture}

Women's unprecedented rise in cofradía politics corresponds to the shift by men from shellfishing to mussel mariculture, which is managed separately. Since 1983, the number of marisquadoras had remained constant at 800, but by 1991 there were only 450 men shellfishing. The total number of people shellfishing had fallen to 1,250. Almost half the men had shifted out of shellfishing and into what they thought to be the more financially secure and lucrative mussel mariculture, using bateas (mussel mariculture rafts). Although men working on bateas remained members of the same cofradia, they established a separate active association and auction market. This drastic new shift in gender balance and in political interest facilitated the acceptance of professional marisquadoras in cofradía politics.

No woman had entered the political organization of the mussel fishery, despite women working along side their men on the bateas. Every batea had 500 12-m-long trailing ropes, 12-m-long, each of which the family harvested every 18 months on a rotating schedule. Women assisted with seeding and harvesting if not enough sons were available. Women also managed the finances of the bateas in their role as family bankers. Moreover, women were part owners of bateas with their brothers, because male and female children all inherited portions of the bateas, as well as garden land following Galician custom (C.Lisón Tolosana 1979). ${ }^{11}$

Bateas are an important source of income for marisquadoras and their families, but not a source of individual identity and status. Women are not competing with men by claiming local status as professional mussel growers. This art is perceived to be male, like 
fishing from vessels. Women only thought to run for office in the cofradia where they had attained professional status in a distinct fishing art, and in a separate fishing zone where the gender ratio was favorable and they did not have as much direct competition with men.

\section{Potential Ecological Threats to Shellfishing}

Paradoxically, bateas, if their growth were left unchecked, could harm water quality and the marisquadoras art. By 1991, the Xunta placed a moratorium on adding more bateas because the rafts had become so numerous that they formed a "wall" that impeded water circulation and threatened ria water quality. In addition, mussel waste was clouding the water and building up thick layers of polluting sediment in the ria bed.

Simultaneously, the very Galician infrastructure development that triggered the shellfish revolution was about to threaten the natural riches of the ria. Ria de Arousa was in a burgeoning area south of Santiago de Compostela, the seat of the Xunta. The 40 towns on the ria were expanding. Increased development was leading to water quality problems for the ria. The shellfish industry had to face the reality of pollution from sewage, dredging, and factories, with the ria no longer able to flush itself clean every few days (Enrique Lopez Veiga, personal communication). In addition, a recent major oil tanker spill in La Coruña diverted Xunta resources towards cleanup, and threatened the quality and reputation of Galician shellfish. All of this jeopardized the very difference in quality that the Xunta hoped to market in order to distinguish the more expensive Galician shellfish from similar species flooding into Spain from the fellow EC states of Italy, Greece, and France.

The Xunta wanted to compete with the influx of EC shellfish by harvesting shellfish year-round, abolishing the fishing season that was originally determined by the canneries. The Xunta also recognized the importance of public image making in marketing shellfish. Thus, it planned to set up a Galician quality label to justify the comparatively high prices. The label would guarantee a unique Galician product fleshiness, size, texture, and taste. The guarantee, coupled with the development of a local conservation plan, might enable marisquadoras to continue marketing their shellfish at a price that could sustain the women's independent income and political status in the community.

\section{Conclusion}

In Illa, we see that women's political involvement and power in the control of resource use was facilitated by the historical convergence of macrostructural changes, the local culture of marisquadoras, and the hiring of Lojo, an educated, politically progressive Illa man, as the cofradía's professional director. Given the bureaucratized fishing sector and its regulation requirements, local participation in management and cooperation with external authorities is not possible without such a formally educated local as intermediary.

The consequences for Illa of this dramatic change in community governance have been threefold. First, a new class of professional marisquadoras evolved with political power and economic stature. They expanded beyond their own fishing art to become

11. The Galician inheritance pattern parcelled out land to every child, so that land had become subdivided into tiny bits, making it difficult to develop, but guaranteeing food security. 
officers of the cofradia and its OP. What impact this will have on gender roles and social organization at the household level remains to be investigated. It is clear that women were positioned for their new political status in progressive co-management by the sexual division of labor in shellfishing and the role of women as marisquadoras and family bankers. Second, Illa gained a favored status with the Xunta whereby they receive funding for village-level and locally-placed development projects. Third, given community support and cooperation in conservation and co-management, Illa could have a more sustainable resource with longer-term revenues.

A major point is the ability to generalize the Illa de Arousa's experience. As seen from the comparison with Cambados, is not even possible to generalize within the ria. Illa's co-management is not replicable through the process of bureaucratization, because of its unique social situation of hiring a local, professional director. It is important to see how the contrast between Cambados and Illa demonstrates both the advantages and disadvantages of small, relatively insular communities for co-management. It is easier for cofradía leaders to institute conservation measures among kin and friends, given their faith and "confianza" in each other, local solidarity and pride. On the other hand, take the example of harvests during poor tides when neighbors must look the other way as juveniles are slipped into the basket. A Spanish proverb on tolerance--Anything for your friends, the law for your enemies-- comes into play. The balance is between mutual trust and cohesion in building up a conservation ethic, and the necessity to tolerate neighbors even as they bend regulations. In this balance, Illa has been able to focus organizational energy and strengths on the trust side, whereas Cambados is caught up on the tolerance side. The juxtaposition between the way the Xunta is attempting to impose regulation on the Cambados' state of persistent free-for-all while rewarding Illa's self-imposed regulation underscores a major theoretical point. People in our bureaucratized world have the proclivity to resolve the Cambados-type problem by moving control upward to broader, more forceful levels. Helicopter conservation patrols swoop over the heads of irate, hoe-brandishing marisquadoras brandishing hoes. The concept is the reverse in comanagement. The aim is to guide Cambados-type communities toward Illa-type solutions. This requires convincing a community that it is in their best interest to match local-level recource use with state and EC management concerns.

Illa, despite co-management, exists in a broader economic, political, and environmental context that threatens to overwhelm its ability to manage the resource. The macrostructural changes beyond Illa's fishing culture that created the shellfish revolution in the first place, such as the integration of Europe and post-Franco development, are still evolving. The emerging concerns include reduction of water quality resulting from increasing population density around the ria, demand for high quality shellfish in order to maintain a high price, the EC market pressures, and rivalry from fellow EC states. Although local solutions and conservation efforts are important both to environmental preservation and to the real empowerment of women within communities to control resource use, in and of themselves they cannot be the model or the solution to degradation and loss of resource control. Thus, the Xunta will have to move beyond envisioning Illa and her marisquadoras as the model solution. ${ }^{12}$

12. The harder work will involve insuring that other communities and their marisquadoras participate in conservation, reducing the pressure on communities to overproduce, and larger-scale efforts to control regional environmental degradation. 


\section{References}

Berkes, Fikret

1986 Local Level Management and the Commons Problem. Marine Policy 10:215-229

Bryant, Raymond

1992 Political Ecology, an Emerging Resource Agenda in Third World Studies.

Political Geography 11(1):12-36.

Cole, Sally

1991 Women of the Praia: Works and Lives in a Portuguese Coastal Community. Princeton, NJ: Princeton University Press.

Dahl, C.

1988 Traditional Marine Tenure: A Basis for Artisanal Fisheries Management. Marine Policy:40-48.

Davis, A.

1985 Property Rights and Access Management in the Small Boat Fishery: A Case Study From South Western Nova Scotia. In C. Lamson and A. Hanson, eds., Atlantic Fisheries and Coastal Communities: Fisheries Decision-Making Case Studies. Halifax, Nova Scotia: Dalhousie University.

Dyer, Christopher L. and James R. McGoodwin

1994 Folk Management in the World's Fisheries: Lessons for Modern Fisheries Management. Niwot, Colorado: University Press of Colorado.

Gonzalez, Vidal M.

1980 El conflicto en el sector marisquero de Galicia.Madrid:AKAL.

Hoefnagel, Ellen

1991 Seaweed, Status and the Symbolic Domain: Seaweed Harvesters in Portuguese Coastal Communities. MAST 4(2):40-61.

Jentoft, Svein

1989 Fisheries Co-management: Delegating Government Responsibility to Fishermen's Organizations. MarinePolicy (April):137-154.

Jentoft, Svein and Trond I. Kristoffersen

1989 Fishermen's Co-management: The Case of the Loftoten Fishery. Human organization 48(4):355-365.

Jentoft, Svein and Knut H. Mikalsen

1994 Regulating Fjord Fisheries: Folk Management or Interest Group Politics? In Christopher Dyer and James McGoodwin (Eds.), Folk Management in the World's Fisheries: Lessons for Modern Fisheries Management. Eds. Niwot, Colorado: University Press of Colorado. Pp.287-316.

Lisn Tolosana, C. 1979 Antropologia Cultural de Galicia. Madrid:AKAL.

McCay, Bonnie J., and James M. Acheson (eds.) 1987 The Question of the Commons: The Culture and Ecology of Communal Resources. Tucson:University of Arizona Press.

Meltzoff, Sarah Keene and Edward LiPuma 1986 The Troubled Seas of Spanish Fishermen: Marine Policy and the Economy of Change. American Ethnologist. Vol. 13 (4), pp. 681-699.

McGoodwin, James R.

1990 Crisis in the World Fisheries: People, Problems, and Policies. Stanford, CA: Stanford University Press. 
Nadel-Klein, Jane and Donna Lee Davis, eds. 1988 To Work and to Weep: Women in Fishing Economies. St. John's, Newfoundland, Canada: Institute of Social and Economic Research, Memorial University of Newfoundland.

Neumann, Roderick 1992 Political Ecology of Wildlife Conservation in the Mt. Meru Area of NE Tanzania. Land Degradation and Rehabilitation 3:85-98.

Ong, Aihwa 1991 The Gender and Labor Politics of Postmodernity. Annual Review of Anthropology 20:279-309.

Pinkerton, Evelyn W.

1994 Summary and Conclusions. In Christopher Dyer and James McGoodwin (Eds.), Folk Management in the World's Fisheries: Lessons for Modern Fisheries Management. Niwot: University Press of Colorado. Pp. 317-337.

Pollnac, Richard B.

1988 Social and Cultural Characteristics of Fishing Peoples. Marine Behavior Physiology 14:23-39.

Thompson, Paul

1985 Women in the Fishing: The Roots of Power Between the Sexes. Comparative Studies in Society and History 27(1):3-32.

Volkman, Toby Alice

1994 Our Garden is the Sea: Contingency and Improvisation in Mandar Women's Work. American Ethnologist 21(3): 564-585.

Xunta de Galicia, Concellera de Pesca

1990-1991Resultados da Campaa Marisqueira 1990-91. Secretara Xeral Tcnica: Estadstica Marisqueira. 


\section{Abstract}

This paper explores connections between macro-structural changes and local fisheries management on Illa de Arousa, Ria de Arousa, Galicia, Spain to understand political ecology. It examines the political rises of marisquadoras (women shellfishers) in the "shellfishing revolution." This revolution was not in technology, but in management and marketing resulting from infrastructural development. The community responded by resurrecting the cofradía (local fisheries association), to create a bureaucartized form of co-management with the Galician government. The historical convergence of marcostructural changes and local culture facilitated marisquadoras' inclusion in comanagement and creation of a local ethnic of conservation.

Key Words: fishing communities, shellfish, co-management, conservation, gender, political ecology, Galicia, Spain, European Community

\section{Resumé}

L'article étudie les relations entre les changements macro-structurales el la gérance de pêcheries locales sur l'Ila de Arosa, Ria de Arousa, Galicie, Espagne pour comprendre l'ecologie politique. Il examine l'élévation politique des marisquadoras (pêcheuses de crustacés) dans la "révolution de crustacés." Cette révolution n'était pas une révolution de technologie, mais de gérance et de marketing-- le résultat de développement d'infrastructure. La communauté a réagit en résurrectant la cofradia (une association de pêcheries locale), avec l'intention de créer une forme bureaucratique de gérance jointe avec le gouvernement Galicien. La convergence historique des changements macrostructurales et la culture locale ont facilité l'inclusion d'une gérance jointe, et la création d'une éthique local de préservation.

Mot Clefs: communautés de pêche, crustacés, gérance jointe, préservation, genre, écologie politique, Galicie, Espagne, Communauté Européene.

\section{Resumen}

Este artículo examina las relaciones entre cambios macro-estructurales y el manejo de pesquerias locales en la Illa de Arousa, Ria de Arousa, Galicia, España para comprender la ecología-política. Se examina el levantamento política de marisquadoras (pescadoras de mariscos) en la "revolución de mariscos." Esta revolucíon no fue de tecnología sino de manejo y comercialización generados por el desarrollo de infraestructura. En repuesta la comunidad resucito la cofradia (como una asociación de pescadores locales), creando así una forma burocratica de co-manejo con el gobierno de Galicia. La convergencia histórica de cambios macro-estructurales y de cambios de la cultura local ha facilitado la inclusión de marisquadoras en el co-manejo y la creacion de un ético local de conservación.

Palabras Claves: comunidades de pescadores, mariscos, manejo co-junto, conservación, género, ecología política, Galicia, España, Comunidad Europea. 